\title{
PENGEMBANGAN PERANGKAT PEMBELAJARAN MODEL COOPERATIVE PROBLEM SOLVING UNTUK MELATIHKAN KETERAMPILAN PEMECAHAN MASALAH SISWA
}

\author{
Irma Permata Sari, Sutarno, Eko Swistoro \\ Program Studi Pendidikan Fisika FKIP, Jurusan pendidikan MIPA \\ Fakultas Keguruan Dan Ilmu Pendidikan Universitas Bengkulu \\ Jl. WR. Supratman, Bengkulu 38123 \\ e-mail*1: irmapermataaa.s@gmail.com
}

\begin{abstract}
ABSTRAK
Penelitian ini yang bertujuan untuk mendeskripsikan kelayakan dan karakteristik perangkat pembelajaran model cooperative problem solving untuk melatihkan keterampilan pemecahan masalah siswa pada materi momentum dan impuls. Model pengembangan yang digunakan pada penelitian ini adalah model pengembangan 4D, yaitu define, design, develop dan disseminate namun hanya dilakukan sampai tahap develop. Validasi dilakukan oleh 3 judgement ahli untuk menilai produk yang dikembangkan. Kelayakan perangkat pembelajaran ini menurut nilai rata-rata hasil uji validasi ahli yaitu kelayakan RPP adalah 89\% dalam kategori sangat layak, kelayakan LKS 91\% dalam kategori sangat layak dan kelayakan soal tes $89 \%$ dalam kategori sangat layak dengan nilai rata-rata keseluruhan $90 \%$ dalam kategori sangat layak sehingga dapat disimpulkan bahwa perangkat pembelajaran yang dikembangkan sudah layak, dengan karakteristik perangkat pembelajaran antara lain: RPP menggunakan langkah-langkah kegiatan pembelajaran model cooperative problem solving, LKS yang berisi kegiatan praktikum dengan langkah-langkah penyelesaian masalah yang bertujuan melatihkan keterampilan pemecahan masalah siswa dan soal tes beserta jawaban atau penyelesaian soal yang melatihkan keterampilan pemecahan masalah siswa.
\end{abstract}

Kata kunci: penelitian dan pengembangan, perangkat pembelajaran, cooperative problem solving, keterampilan pemecahan masalah

\begin{abstract}
The research aimed to describe the feasibility and characteristics of a cooperative problem solving model of learning tools to train students' problem solving skills in momentum and impulse material. The development model used in this research is the 4D development model, namely define, design, develop and disseminate but only done until the develop stage. Validation is carried out by 3 expert judgments to assess the product being developed. The feasibility of this learning device according to the average value of the expert validation test results, namely the feasibility of the RPP is $89 \%$ in the very feasible category, the feasibility of the LKS $91 \%$ in the very feasible category and the feasibility of the test questions $89 \%$ in the very feasible category with an overall average score of $90 \%$ in the very feasible category so it can be concluded that the learning tools developed are feasible, with the characteristics of the learning tools, among others: RPP uses the steps of learning activities in the cooperative problem solving model, worksheets containing practicum activities with problem solving steps aimed at practicing solving skills student problems and test questions along with answers or problem solving that practice student problem solving skills.
\end{abstract}

Keywords: Research and development, learning tools, cooperative problem solving, problem solving skills

\section{PENDAHULUAN}

Sistem pembelajaran abad ke-21 merupakan suatu pembelajaran yang menuntut sekolah untuk mengubah pendekatan pembelajaran yang awalnya berpusat pada guru menjadi pendekatan pembelajaran yang berpusat pada siswa, agar siswa memiliki kemampuan berpikir dan belajar sesuai tuntutan masa depan (Febrina Sanderi, Marjohan, 2013). Pembelajaran di abad 21 menuntut siswa untuk memiliki keterampilan belajar dan berinovasi baik menggunakan teknologi dan media informasi, dapat bekerja, dan bertahan menggunakan keterampilan untuk hidup. Keterampilan tersebut dapat diperoleh siswa yaitu dengan proses pembelajaran yang dialami siswa.

Kurikulum 2013 dikembangkan melalui pendekatan pembelajaran yang berpusat pada siswa (student-centered learning) sesuai dengan paradigma pembelajaran abad 21. Dalam konteks 
pembelajaran kurikulum 2013, keterampilan abad 21 diistilahkan dengan 4C yaitu (Communication, Collaboration, Critical Thinking and Problem Solving, Creativity and Innovation). Keterampilan pemecahan masalah merupakan salah satu keterampilan di abad 21 yang harus dikuasai siswa. Keterampilan pemecahan masalah merupakan komponen penting dalam disiplin ilmiah, termasuk fisika (Maryati, 2018).

Perangkat pembelajaran yang digunakan oleh guru menjadi salah satu kunci bagi siswa untuk belajar dengan baik. Upaya untuk meningkatkan kemampuan siswa adalah menggunakan perangkat pembelajaran dengan model pembelajaran yang melibatkan aktivitas siswa, sikap dan keterampilan siswa. Sumartini (2016) menegaskan bahwa pembelajaran berbasis masalah (problem solving) dirancang untuk membantu siswa mengembangkan keterampilan berpikir, keterampilan menyelesaikan masalah, dan keterampilan intelektualnya (Puadi, 2017). Model pembelajaran yang diyakini efektif untuk meningkatkan keterampilan pemecahan masalah siswa adalah model pembelajaran cooperative problem solving..

Model cooperative problem solving adalah model pembelajaran yang menuntut siswa agar dapat menyelesaikan permasalahan secara bersama-sama dalam kelompok yang telah di bentuk (Heller \& Heller, 2010). Model pembelajaran cooperative problem solving berpusat pada pengajaran dan keterampilan pemecahan masalah sehingga diharapkan membuat siswa mampu mengembangkan kemampuannya dalam menyelesaikan pemecahan masalah (Widodo \& Kadarwati, 2013).

Berdasarkan hasil studi awal di salah satu SMA Negeri yang ada di Kota Bengkulu memperlihatkan bahwa proses pembelajaran masih berpusat kepada guru, sehingga sangat dibutuhkan bahan ajar yang mampu membuat proses pembelajaran berpusat kepada siswa sesuai dengan tuntutan kurikulum 2013, dan yang mampu membekalkan kemampuan keterampilan pemecahan masalah siswa. Dalam kegiatan pembelajaran, sebagian guru menggunakan Lembar Kerja Siswa yang bukan buatan guru sendiri sehingga terkadang tidak sesuai dengan karakteristik siswa.

Keterampilan pemecahan masalah sangat dibutuhkan dalam proses pengkonstruksian pengetahuan peserta didik lebih lanjut. Keterampilan ini akan berkembang dengan baik apabila proses pembelajaran secara sengaja diarahkan untuk mengembangkannya (Sutarno, Setiawan, Suhandi, Kaniawati, \& Putri, 2017). Siswa harus memiliki kemampuan memecahkan berbagai masalah kontekstual secara kritis dan kreatif dan pemecahan masalah merupakan salah satu kunci penting bagi perkembangan kreativitas seseorang (Saputra, 2020). Pengajaran tentang pemecahan masalah harus memperhatikan jenis masalah yang ingin dipecahkan, (Wena, 2012). Kemampuan pemecahan masalah merupakan hal yang sangat penting untuk masa depan siswa. Kemampuan pemecahan masalah dapat dibentuk melalui bidang studi dan disiplin ilmu yang diajarkan dalam batas-batas tertentu (Suharsono, 1991).

Perangkat pembelajaran merupakan bagian penting dalam pelaksanaan pendidikan disekolah yaitu untuk membantu siswa dalam memahami konsep, prosedur, dan teori untuk mencapai tujuan pembelajaran. Perangkat pembelajaran memuat bahan ajar yang dapat mengatasi keterbatasan pengalaman yang dimiliki siswa (Miarso, 2007). Perangkat pembelajaran diperlukan dalam mengelola proses pembelajaran berupa silabus, RPP, LKS, instrumen evaluasi atau tes hasil belajar, media pembelajaran serta buku ajar peserta didik (Trianto, 2007).

Penelitian terdahulu menunjukkan bahwa perangkat pembelajaran berbasis problem solving terbukti dapat digunakan sebagai perangkat pembelajaran untuk meningkatkan keterampilan berpikir tingkat tinggi siswa (Dewi, Sriyono, \& Ashari, 2015). Penelitian lainnya menunjukkan bahwa perangkat pembelajaran berbasis problem solving yang telah dikembangkan dapat digunakan guru untuk menggali dan mengembangkan potensi/kemampuan yang dimiliki peserta didik dalam memecahkan masalah (Muzanni \& Muhyadi, 2016). Penelitian selanjutnya menunjukkan bahwa produk hasil pengembangan yaitu RPP dan LKPD termasuk di dalamnya instrumen tes dengan strategi pemecahan masalah memenuhi kriteria kevalidan dan didapatkan hasil bahwa nilai prestasi 
maupun pemecahan masalah meningkat setelah menggunakan produk LKPD dan RPP yang dikembangkan (Susanto \& Suri, 2017).

Berdasarkan uraian diatas, maka perlu dilakukan penelitian untuk mengembangkan perangkat pembelajaran model cooperative problem solving. Perangkat pembelajaran yang akan dihasilkan diharapkan dapat digunakan untuk melatihkan keterampilan pemecahan masalah siswa pada Materi momentum dan impuls.

\section{METODEPENELITIAN}

Metode penelitian R\&D merupakan sebuah metode penelitian yang digunakan untuk menghasilkan produk tertentu (Sugiyono, 2010). Penelitian ini menggunakan model 4D yang meliputi define, design, develop dan disseminate namun hanya dilakukan hingga tahap develop. Tahap disseminate tidak dapat dilakukan akibat Covid-19. Tahapan penelitian pada model ini bisa dilihat pada gambar 1.

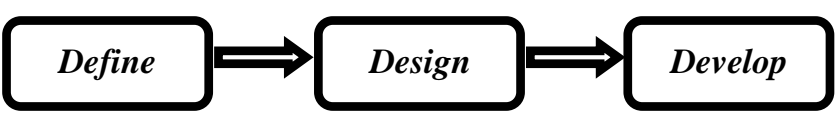

Gambar 1. Tahapan penelitian

Peneitian ini dilaksanakan di SMA N 5 Kota Bengkulu. Produk yang dikembangkan adalah perangkat pembelajaran model cooperative problem solving untuk melatihkan keterampilan keterampilan pemecahan masalah siswa pada materi momentum dan impuls. Penilaian kelayakan perangkat pembelajaran ini akan divalidasi oleh 3 orang validasi ahli, yaitu 2 orang dosen (expert judgement) dan seorang guru (praktisi). Data hasil validasi selanjutnya dianalisis menggunakan rumus pada persamaan 1:

$$
\% \text { Interpretasi skor }=\frac{\sum \text { skor perolehan }}{\sum \text { skor maksimum }} \times 100 \% \quad \text { Persamaan (1) }
$$

Setelah didapatkan interpretasi skor dengan menggunakan persamaan 1, maka diperoleh persentase skor. Persentase skor dapat dilihat pada tabel 2.

Tabel 2. Interpretasi Skor Penilaian

\begin{tabular}{cc}
\hline Persentase & Kategori \\
\hline $82 \% \leq \mathrm{P}<100 \%$ & Sangat layak \\
$63 \% \leq \mathrm{P}<82 \%$ & Layak \\
$44 \% \leq \mathrm{P}<63 \%$ & Kurang layak \\
$25 \% \leq \mathrm{P}<44 \%$ & Tidak layak \\
\hline
\end{tabular}

\section{HASIL DAN PEMBAHASAN}

\subsection{Hasil}

\subsubsection{Define (Tahap Pendefinsian)}

Tahap pendefinisian merupakan kegiatan untuk menetapkan kebutuhan dan mendefinisikan syarat-syarat pengembangan yang akan dilakukan. Tahap pendefinisian ini bertujuan untuk mengumpulkan informasi yang berkaitan dengan poduk yang akan dikembangkan. Kegiatan yang dilakukan pada tahap ini adalah penyusunan instrumen untuk tahap define, analisis perangkat pembelajaran berupa RPP, LKS dan soal tes serta analisis kebutuhan.

Hasil analisis yang telah dilakukan yaitu RPP Konsep inti di dalam Rencana Pelaksanaan Pembelajaran (RPP) pada materi momentum dan impuls yang digunakan disekolah yaitu momentum, impuls dan tumbukan lenting sempurna, lenting sebagian dan tidak lenting sama sekali. Kompetensi dasar materi ini yaitu 3.10 Menerapkan konsep momentum dan impuls, serta hukum kekekalan momentum dalam kehidupan sehari-hari dan 4.10 Menyajikan hasil pengujian penerapan hukum kekalan momentum, misalnya bola jatuh bebas ke lantai dan roket sederhana. Model yang digunakan didalam RPP bukan model pembelajaran cooperative problem solving. LKS berisikan 
langkah-langkah kerja yang disajikan secara runtut, namun kegiatan praktikum pada LKS tidak mengikuti lagkah-langkah pada model cooperative problem solving seperti yang akan dikembangkan dan soal tes yang digunakan belum bertujuan untuk melatihkan keterampilan pemecahan masalah siswa, hal ini terlihat dari belum adanya langkah-langkah pemecahan masalah yang diterapkan untuk penyelesaian soal.

Hasil analisis kebutuhan diperoleh dari observasi kegiatan pembelajaran fisika di sekolah dan data-data sekunder dari penelitian terdahulu terkait pentingnya pengembangan perangkat pembelajaran model cooperative problem solving. Berdasarkan data yang telah diperoleh dapat disimpulkan bahwa diperlukan alternatif produk pengembangan berupa perangkat pembelajaran yang dapat melatihkan keterampilan pemecahan masalah siswa. Salah satu perangkat pembelajaran yang sesuai dengan kriteria tersebut adalah perangkat pembelajaran model cooperative problem solving.

\subsubsection{Design (Tahap Perancangan)}

Tahap ini dilakukan setelah melakukan tahap define. Hasil perancanagan produk yang dikembangkan adalah modul perangkat pembelajaran model cooperative problem solving untuk melatihkan keterampilan pemecahan masalah siswa. Perangkat pembelajaran terdiri dari Rencana Pelaksanaan Pembelajaran (RPP), Lembar kerja Siswa (LKS), dan soal tes. RPP terdiri dari identitas mata, kompetensi dasar, tujuan pembelajaran, model pembelajaran, media pembelajaran, kegiatan pembelajaran, penilaian, pengesahan. LKS terdiri dari judul, kompetensi dasar, tujuan pembelajaran, ringkasan materi, permasalahan, tahap penyelesaian masalah dan kesimpulan. Soal tes terdiri dari 5 butir soal dimana tahapan penyelesaian soal mengikuti langkah-langkah cooperative problem solving yang terdiri dari 5 indikator penyelesaian masalah.

\subsubsection{Develop (Tahap Pengembangan)}

Tahap develop merupakan tahap pengembangan. Tahap ini terdiri dari validasi ahli dan revisi berdasarkan hasil validasi ahli. Perhitungan hasil validasi ahli terhadap Rencana Pelaksanaan Pembelajaran (RPP) dapat dilihat pada tabel 3.

Tabel 3. Hasil validasi RPP

\begin{tabular}{ccccc}
\hline Validator & $\begin{array}{c}\sum \text { Skor } \\
\text { perolehan }\end{array}$ & $\begin{array}{c}\sum \text { Skor } \\
\text { maksimum }\end{array}$ & $\begin{array}{c}\text { \%interpretasi skor } \\
\frac{\sum}{N} X 100 \%\end{array}$ & Kategori \\
\hline Ahli 1 & 127 & 140 & $90 \%$ & Sangat layak \\
Ahli 2 & 137 & 140 & $97 \%$ & Sangat layak \\
Praktisi & 111 & 140 & $79 \%$ & Layak \\
Total & $\mathbf{3 7 5}$ & $\mathbf{4 2 0}$ & $\mathbf{8 9 \%}$ & Sangat layak \\
\hline
\end{tabular}

Berdasarkan tabel 3 dapat disimpulkan bahwa hasil rata-rata validasi ahli terhadap aspek isi pada modul yang dikembangkan berada pada kategori "sangat layak" dengan persentase sebesar $89 \%$ dari persentase maksimum yaitu $100 \%$. Perhitungan hasil validasi ahli terhadap Lembar Kerja Siswa (LKS) dapat dilihat pada tabel 4.

Tabel 4. Hasil validasi LKS

\begin{tabular}{ccccc}
\hline Validator & $\begin{array}{c}\sum \text { Skor } \\
\text { perolehan }\end{array}$ & $\begin{array}{c}\sum \text { Skor } \\
\text { maksimum }\end{array}$ & $\begin{array}{c}\text { \%interpretasi skor } \\
\frac{\sum R}{N} \times 100 \%\end{array}$ & Kategori \\
\hline Ahli 1 & 71 & 76 & $93 \%$ & Sangat layak \\
Ahli 2 & 72 & 76 & $93 \%$ & Sangat layak
\end{tabular}




\begin{tabular}{ccccc} 
Praktisi & 66 & 76 & $86 \%$ & Sangat layak \\
Total & $\mathbf{2 0 8}$ & $\mathbf{2 2 8}$ & $\mathbf{9 1 \%}$ & Sangat layak \\
\hline
\end{tabular}

Berdasarkan tabel 4 dapat disimpulkan bahwa hasil rata-rata validasi ahli terhadap aspek penyajian pada modul yang dikembangkan berada pada kategori "sangat layak" dengan persentase sebesar $91 \%$ dari persentase maksimum yaitu $100 \%$. Perhitungan hasil validasi ahi terhadap soal tes dapat dilihat pada tabel 5.

Tabel 5. Hasil validasi soal tes

\begin{tabular}{ccccc}
\hline Validator & $\begin{array}{c}\sum \text { Skor } \\
\text { perolehan }\end{array}$ & $\begin{array}{c}\sum \text { Skor } \\
\text { maksimum }\end{array}$ & $\begin{array}{c}\text { \%interpretasi skor }= \\
\frac{\sum R}{N} X 100 \%\end{array}$ & Kategori \\
\hline Ahli 1 & 51 & 60 & $85 \%$ & Sangat layak \\
Ahli 2 & 57 & 60 & $95 \%$ & Sangat layak \\
Praktisi & 53 & 60 & $87 \%$ & Sangat layak \\
Total & $\mathbf{1 6 1}$ & $\mathbf{1 8 0}$ & $\mathbf{8 9 \%}$ & Sangat layak \\
\hline
\end{tabular}

Berdasarkan tabel 5 dapat disimpulkan bahwa hasil rata-rata validasi ahli terhadap soal tes yang dikembangkan berada pada kategori "sangat layak" dengan persentase sebesar 90\% dari persentase maksimum yaitu $100 \%$. Hasil total validasi ahli terhadap 3 aspek penilaian oleh 2 orang judgement ahli dan seorang praktisi berada pada kategori "sangat layak" dengan persentase $89 \%$. Hal ini membuktikan bahwa perangkat pembelajaran model cooperative problem solving untuk melatihkan keterampilan pemecahan masalah siswa yang dikembangkan layak diujicobakan dengan adanya beberapa revisi.

Setelah melakukan validasi ahli dan revisi berdasarkan hasil validasi ahli maka diperoleh sebuah produk akhir berupa perangkat pembelajaran model cooperative problem solving untuk melatihkan keterampilan pemecahan masalah siswa pada materi momentum dan impuls. Perangkat pembelajaran yang dikembangkan meliputi Pelaksanaan Pembelajaran (RPP), Lembar kerja Siswa (LKS), dan soal tes.

\subsection{Pembahasan}

Penelitian ini merupakan penelitian pengembangan dengan tahapan yang terdiri dari define, design, dan development. Hasi penelitian ini adalah perangkat pembelajaran model cooperative problem solving untuk melatihkan keterampilan pemecahan masalah siswa dalam bentuk cetak.

a. Kelayakan perangkat pembelajaran

Tahap ini dilakukan untuk mendeskripsikan kelayakan perangkat pembelajaran Cooperative Problem Solving untuk melatihkan keterampilan pemecahan masalah siswa berdasarkan validasi ahli. Angket validasi produk yang dinilai oleh validator terdiri dari beberapa aspek, untuk RPP terdiri dari aspek identitas, ketepatan alokasi waktu, perumusan tujuan pembelajaran, materi pembelajaran, pemilihan model pembelajaran, pemilihan sumber belajar, pemilihan media pembelajaran,langkah kegiatan pembelajaran dan penilaian. Angket validasi LKS terdiri dari aspek komponen LKS, materi pembelajaran, kesesuaian LKS dengan syarat didaktik, kesesuaian LKS dengan syarat konstruksi, dan kesesuaian LKS dengan syarat teknis. Validasi soal tes terdiri dari beberapa aspek yaitu aspek teknik penilaian, kelengkapan instrumen, kesesuaian isi, konstruksi soal dan aspek kebahasaan.

Berdasarkan hasil keseluruhan dari uji validasi yang dilakukan atau dinilai oleh 2 orang judgement ahli dan seorang praktisi maka dapat dikatakan bahwa perangkat pembelajaran Cooperative Problem Solving untuk melatihkan keterampilan pemecahan masalah siswa yang dikembangkan tergolong dalam kategori sangat layak dengan persentase rata-rata sebesar $90 \%$ dari $100 \%$, dimana untuk RPP yang dikembangkan tergolong dalam kategori sangat layak dengan persentase rata-rata sebesar $89 \%$ dari $100 \%$, untuk LKS yang dikembangkan tergolong dalam 
kategori sangat layak dengan persentase rata-rata sebesar $91 \%$ dari $100 \%$ dan soal tes yang dikembangkan tergolong dalam kategori sangat layak dengan persentase rata-rata sebesar $89 \%$ dari 100\%. Sehingga dapat disimpulkan bahwa perangkat pembelajaran Cooperative Problem Solving untuk melatihkan keterampilan pemecahan masalah siswa sudah layak untuk diujicobakan ke lapangan akan tetapi perlu adanya beberapa revisi.

b. Karakteristik perangkat pembelajaran

Karakteristik Rencana Pelaksanaan Pembelajaran (RPP) yang dikembangkan yaitu Rencana Pelaksanaan Pembelajaran (RPP) menggunakan model pembelajaran cooperative problem solving dengan media pembelajaran yang digunakan yaitu media simulasi PhET. Sedangkan pada Rencana Pelaksanaan Pembelajaran (RPP) yang digunakan di sekolah model yang digunakan yaitu pembelajaran langsung dengan media pembelajaran yaitu powerpoint.

Kegiatan pembelajaran pada RPP yang dikembangkan terdiri dari kegiatan pendahuluan, kegiatan inti dan kegiatan penutup. Pada kegiatan inti tahapan pelaksanaan pembelajaran memuat kelima indikator model pembelajaran cooperative problem solving yaitu memahami masalah (recognize the problem), mendeskripsikan masalah (Describe the problem in terms of the field), merencanakan solusi (Plan a solution), melakukan penyelesaian masalah (Execute the problem ), dan evaluasi (Evaluate the solution).

Karakteristik Lembar Kerja Siswa (LKS) yang dikembangkan yaitu LKS memuat tujuan pembelajaran, terdapat ringkasan materi pembelajaran, dan kegiatan pada LKS memuat indikator cooperative problem solving. LKS yang dikembangkan bertujuan untuk menuntun siswa melakukan kegiatan pemecahan masalah dengan menggunakan tahapan cooperative problem solving sehingga dapat melatihkan keterampilan pemecahan masalah siswa. LKS dimulai dengan memberikan berbagai permasalahan berkaitan materi momentum dan impuls sebagai umpan yang mengarah pada materi, diskusi, praktikum atau percobaan sederhana, serta evaluasi berupa soal yang bertujuan untuk mengasah kemampuan berpikir kritis dan kepahaman siswa. Materi yang disajikan dalam LKS berbasis pendekatan pemecahan masalah adalah momentum dan impuls yang meliputi sub materi hubungan impuls dan momentum, hukum kekekalan momentum, serta jenis-jenis tumbukan.

Karakteristik soal tes yang dikembangkan yaitu setiap butir soal berisikan lima pertanyaan yang mengarahkan siswa untuk menyelesaikan soal dengan tahapan pemecahan masalah. Tahapan penyelesaian masalah terdiri dari 5 indikator yaitu memahami masalah (recognize the problem), mendeskripsikan masalah (describe the problem in physics description), merencanakan solusi (Plan a solution), melakukan penyelesaian masalah (Execute the problem), dan evaluasi (Evaluate the solution) sehingga dapat melatihkan keterampilan pemecahan masalah siswa.

Penelitian ini relevan dengan penelitian yang dilakukan oleh Anggita, dkk (2015) hasil penelitiannya menunjukkan bahwa perangkat pembelajaran berbasis problem solving terbukti dapat digunakan sebagai perangkat pembelajaran untuk meningkatkan keterampilan berpikir tingkat tinggi siswa. Muzani \& Muhyadi (2016) menunjukkan bahwa perangkat pembelajaran berbasis problem solving yang telah dikembangkan dapat digunakan guru untuk menggali dan mengembangkan potensi/kemampuan yang dimiliki peserta didik dalam memecahkan masalah.

\section{SIMPULAN DAN SARAN}

\subsection{Simpulan}

Berdasarkan hasil pengembangan yang telah dilakukan dapat disimpulkan bahwa (1) Kelayakan perangkat pembelajaran yang dikembangkan untuk RPP dikatakan sudah layak dalam kategori sangat layak, untuk LKS dikatakan sudah layak dalam kategori sangat layak dan untuk soal tes dikatakan sudah layak dalam kategori sangat layak sehingga dapat disimpulkan bahwa perangkat pembelajaran yang dikembangkan sudah memenuhi kriteria kelayakan berdasarkan hasil rata-rata uji validasi ahli dan praktisi. (2) Karakteristik perangkat pembelajaran yang telah dikembangkan adalah: a. RPP menggunakan model pembelajaran cooperative problem solving dengan media pembelajaran yang digunakan yaitu media simulasi PhET. Kegiatan pembelajaran terdiri dari kegiatan pendahuluan, inti dan penutup. Pada kegiatan inti tahapan pembelajaran memuat kelima 
indikator model pembelajaran cooperative problem solving yaitu memahami masalah (recognize the problem), mendeskripsikan masalah (Describe the problem in terms of the field), merencanakan solusi (Plan a solution), melakukan penyelesaian masalah (Execute the problem ), dan evaluasi (Evaluate the solution), b. LKS menyajikan fenomena kehidupan sehari-hari sebagai permasalahan yang harus dipecahkan, tujuannya agar siswa termotivasi untuk terlibat aktif dalam kegiatan pemecahan masalah. Penyajian masalah membuat siswa berpikir dan mengasumsi penyelesaian masalah dari pengalaman yang pernah dialami. Guru membimbing siswa dalam melakukan percobaan kelompok untuk mendapatkan solusi dari permasalahan yang dihadirkan pada awal pembelajaran, kemudian menganalisis hasilnya sesuai dengan teori yang ada. Tahap terakhir dalam model cooperative problem solving yaitu mengevaluasi hasil percobaaan bersama kelompok dan mempresentasikan di depan kelas. Pada tahap akhir ini, guru membantu siswa untuk melakukan refleksi atau evaluasi terhadap penganalisisan masalah yang telah dilakukan. C. Soal tes terdiri dari 5 butir soal dimana setiap butir soal berisikan 5 pertanyaan yang mengarahkan siswa untuk melakukan tahapan pemecahan masalah menggunakan kelima indikator pemecahan masalah secara sistematis.

\subsection{Saran}

Berdasarkan hasil pengembangan yang telah dilakukan sebelumnya didapatkan saran (1) Bagi pihak yang bermaksud mengadopsi hasil pengembangan perangkat pembelajaran yang dihasilkan dari penelitian ini hendaknya terlebih dahulu dianalisis kembali untuk disesuaikan penerapannya, terutama dalam hal alokasi waktu dan karakteristik siswa yang ada pada sekolah tempat perangkat akan diterapkan, (2) Hasil penelitian ini diharapkan dapat memacu peneliti lain untuk mengembangkan lebih mendetail, baik pada mata pelajaran fisika maupun pada mata pelajaran lain, (3) Untuk penelitian selanjutnya dapat melakukan tahapan penelitian dan pengembangan secara keseluruhan hingga tahap disseminate (penyebarluasan).

\section{UCAPAN TERIMAKASIH}

Penulis mengucapkan terimakasih kepada validator ahli (Dr. Rosane Medriati, M.Pd., Dr. Afrizal Mayub, M.Pd., dan Popi Susanti, S.Pd.) yang telah membantu dalam penelitian pengembangan produk berupa perangkat pembelajaran fisika.

\section{DAFTAR PUSTAKA}

Dewi, R. A., Sriyono, \& Ashari. (2015). Pengembangan Perangkat Pembelajaran Berbasis Problem Solving untuk Meningkatkan Keterampilan Berpikir Tingkat Tinggi pada Mata Pelajaran Fisika SMA N 3 Purworejo Kelas XI Tahun Pelajaran. Jurnal Berkala Radiasi Pendidikan Fisika Universitas Muhammadiyah Purworejo, 06(1), 64-70.

Febrina Sanderi, Marjohan, I. S. (2013). Febrina Sanderi Marjohan Indah Sukmawat. Peran Guru Bimbingan Dan Konseling Serta Peran Guru Mata Pelajaran Dalam Mengatasi Kesulitan Belajar Siswa Di Sekolah Menengah Atas (Sma) Negeri, 2(3), 120-124.

Heller, K., \& Heller, P. (2010). Cooperative Problem Solving in Physics A User's Manual Can this be true? University of Minnesota, 310.

Maryati, I. (2018). Penerapan Model Pembelajaran Berbasis Masalah Pada Materi Pola Bilangan Di Kelas Vii Sekolah Menengah Pertama. Mosharafa: Jurnal Pendidikan Matematika, 7(1), 6374. https://doi.org/10.31980/mosharafa.v7i1.342

Miarso, Y. (2007). Menyemai benih teknologi pendidikan. Jakarta: Prenoda Media.

Muzanni, A., \& Muhyadi, M. (2016). Pengembangan Perangkat Pembelajaran Problem Solving Mata Pelajaran Ipa Terhadap Hasil Belajar Kognitif Siswa Sd. Jurnal Prima Edukasia, 4(1), 1. https://doi.org/10.21831/jpe.v4i1.7746 
Puadi, E. F. W. (2017). Analisis Peningkatan Kemampuan Koneksi Matematis Mahasiswa Ptik Melalui Pembelajaran Berbasis Masalah. 5.

Saputra, H. (2020). Kemampuan Berfikir Kritis Matematis. Perpustakaan IAI Agus Salim, 2(April), $1-7$.

Sugiyono. (2010). Metode penelitian pendidikan pendekatan kuantitatif, kualitatif dan R\&D. Bandung: Alfabeta.

Suharsono. (1991). Penerapan Model Pembelajaran Pemecahan Masalah Untuk Mengembangkan Kemampuan Berpikir dan Bernalar Mahasiswa. Jakarta: PPS IKIP Malang.

Susanto, F., \& Suri, I. R. A. (2017). PENGEMBANGAN PERANGKAT PEMBELAJARAN MODEL KOOPERATIF TIPE NHT DENGAN STRATEGI PEMECAHAN MASALAH (PROBLEM SOLVING) SISTEMATIS BAGI PESERTA DIDIK SMP DI KABUPATEN PRINGSEWU. 6(3).

Sutarno, S., Setiawan, A., Suhandi, A., Kaniawati, I., \& Putri, D. H. (2017). Keterampilan Pemecahan Masalah Mahasiswa Dalam Pembelajaran Bandul Fisis Menggunakan Model Problem Solving Virtual Laboratory. Jurnal Pendidikan Fisika Dan Teknologi, 3(2), 164. https://doi.org/10.29303/jpft.v3i2.396

Trianto, A. (2007). Model-Model Pembelajaran Inovatif Progresif. Jakarta: Grasindo.

Wena. (2012). Strategi pembelajaran inovatif kontemporer. Jakarta: Bumi Aksara.

Widodo, T., \& Kadarwati, S. (2013). To Improve Learning Achievement. Cakrawala Pendidikan, 32(1), 161-171. 